\title{
Moringa oleifera Lam. Seeds as a Natural Solid Adsorbent for Removal of AgI in Aqueous Solutions
}

\author{
Cleide S. T. Araújo, Edmar I. Melo, Vanessa N. Alves and Nívia M. M. Coelho* \\ Instituto de Química, Universidade Federal de Uberlândia, Av. João Naves de Ávila 2121, \\ 38400-902 Uberlândia-MG, Brazil
}

\begin{abstract}
Este trabalho descreve o potencial de sorção das sementes de Moringa oleifera para descontaminação de $\mathrm{Ag}^{\mathrm{I}}$ em soluções aquosas. Espectroscopia de infravermelho foi usada para elucidação de possíveis grupos funcionais responsáveis pela adsorção de $\mathrm{Ag}^{\mathrm{I}}$. Estudos de adsorção foram feitos em batelada usando soluções padrão de $\mathrm{Ag}^{\mathrm{I}}$ como função da massa do adsorvente, tempo de extração, tamanho da partícula e $\mathrm{pH}$. A Ag ${ }^{\mathrm{I}}$ foi quantificada antes e após os experimentos de remoção usando espectrometria de absorção atômica por chama. Adicionalmente, considerandose os estudos de adsorção e isotermas de adsorção aplicadas ao modelo de Langmuir foi possível verificar que as sementes de $M$. oleifera apresentam alta capacidade de adsorção. As condições ótimas foram: 2,0g de adsorvente com tamanhos de partícula de 75-500 $\mu \mathrm{m}, 100 \mathrm{~mL}$ de solução 25,0 $\mathrm{mg} \mathrm{L}^{-1} \mathrm{Ag}^{\mathrm{I}}$, tempo de extração de $20 \mathrm{~min}$ e $\mathrm{pH}$ 6,5. Os resultados mostram que as sementes de Moringa oleifera podem ser usadas para remoção de $\mathrm{Ag}^{\mathrm{I}}$ em soluções aquosas.
\end{abstract}

This work describes the sorption potential of Moringa oleifera seeds for the decontamination of $\mathrm{Ag}^{\mathrm{I}}$ in aqueous solutions. Infrared spectroscopy was used for elucidating possible functional groups responsible for uptaking $\mathrm{Ag}^{\mathrm{I}}$. Sorption studies using $\mathrm{Ag}^{\mathrm{I}}$ standard solutions were carried out in batch experiments as functions of adsorbent mass, extraction time, particle size and $\mathrm{pH}$. $\mathrm{The}^{\mathrm{Ag}^{\mathrm{I}}}$ was quantified before and after the removal experiments using flame atomic absorption spectrometry. Furthermore, based on adsorption studies and adsorption isotherms applied to the Langmuir model, it was possible to verify that M. oleifera seeds present a high adsorption capacity. The optimum conditions were: $2.0 \mathrm{~g}$ of adsorbent with particle size of $75-500 \mu \mathrm{m}, 100 \mathrm{~mL}$ of $25.0 \mathrm{mg} \mathrm{L}^{-1} \mathrm{Ag}^{\mathrm{I}}$, extraction time of $20 \mathrm{~min}$ and $\mathrm{pH}$ at 6.5. The results show that Moringa oleifera seeds can be used for removing $\mathrm{Ag}^{\mathrm{I}}$ in aqueous solutions.

Keywords: removal, characterization, sorption, Moringa oleifera, silver

\section{Introduction}

Industrial processes have historically been an important factor of environmental degradation. The disposal of industrial wastes, mainly containing metal ions in water sources represents a problem of great concern not only in relation to biota in the receiving environment, but also to humans. Silver is included among the main pollutants because of its high toxicity. ${ }^{1,2}$ Therefore methods to minimize pollution caused by this metal are attractive.

Conventional techniques used for removing metal ions include filtration, precipitation, flocculation, ion exchange resins and reverse osmosis. ${ }^{3}$ However, these technologies have limitations such as high operating cost, incomplete

\footnotetext{
*e-mail: nmmcoelho@ufu.br
}

removal of metal ions and generation of toxic sludge. .-6 $^{-6}$ On the other hand, the biosorption process offers several advantages such as low cost of the biosorbent, high efficiency, minimization of chemical and/or biological sludge and regeneration of biosorbent. ${ }^{7}$

In this way, natural adsorbents constitute an excellent alternative for chemical remediation of heavy metals from aqueous solutions. ${ }^{8-10}$

Microorganisms such as algae, yeast, bacteria and fungi have been widely evaluated as biosorbents for removing metal ions from an aqueous solution. ${ }^{11-13}$ However, biosorption of metal ions onto microorganisms is affected by several factors such as $\mathrm{pH}$, metal concentration, biomass loading, temperature and other parameters.

Lignocellulosic materials such as cane bagasse, onion skins, peanut skins, rice husks, and so on, have been used 
for metal ions adsorption due to the characteristics of the functional groups present in these materials. ${ }^{14}$

Recently, natural adsorbents have been proposed for removing metal ions due to their good adsorption capacity. ${ }^{1}$ In this context, the Moringa oleifera seeds present themselves as an alternative material for this propose. ${ }^{15,16}$

M. oleifera seeds have been used for treating turbid water due to their flocculating properties. A flocculating protein from $M$. oleifera Lam. seeds was isolated by Gassenschmidt et al. (1995). ${ }^{17}$ The molecular protein mass was determined at about $6.5 \mathrm{kDa}$, the isoelectric point was above $\mathrm{pH}$ 10. Flocculation activity could be explained by the patch charge mechanism due to low molecular weight and high charge density.

The present work describes the sorption potential of M. oleifera seeds for decontamination of $\mathrm{Ag}^{\mathrm{I}}$ in aqueous solutions. Variables such as particle size, $\mathrm{pH}$, extraction time and sorbent mass were evaluated. The proposed adsorbent was applied to effluent samples.

\section{Experimental}

\section{Sorbent preparation}

The M. oleifera seeds were obtained from trees which were cultivated in the city of Uberlandia (Minas Gerais, Brazil) and collected from September-November 2007. The seeds were separated from the pods, crushed in a household blender (Black \& Decker, São Paulo, Brazil) and strained through 500, 180 and $75 \mu \mathrm{m}$ sieves.

The functional groups present in $M$. oleifera were characterized by Fourier transform infrared (FT-IR) spectrometer (Shimadzu, IRPrestige-21, Tokyo, Japan). The spectral range varied between 4000 to $500 \mathrm{~cm}^{-1}$, with twenty eight scans in a resolution of $4 \mathrm{~cm}^{-1}$.

\section{Sorption studies}

Removal studies using standard $\mathrm{Ag}^{\mathrm{I}}$ solutions were carried out in triplicate. The seeds were shaken with 50 of $25 \mathrm{mg} \mathrm{L}^{-1} \mathrm{Ag}^{\mathrm{I}}$ for $20 \mathrm{~min}$ using a magnetic agitator and then the suspension was filtered using filter paper (Whatman $42,28 \mu \mathrm{m}) . \mathrm{Ag}^{\mathrm{I}}$ was quantified before and after the removal experiments.

In order to obtain the optimum condition for the percentage of $\mathrm{Ag}^{\mathrm{I}}$ removal, the following variables were studied: particle size of the sorbent (500, 180 and $75 \mu \mathrm{m})$, $\mathrm{pH}(2.0,4.0,6.0$ and 8.0), extraction time $(5,20,35$ and $50 \mathrm{~min})$ and sorbent mass $(0.1,0.2,0.3,0.4,1.0,2.0,3.0$ and $4.0 \mathrm{~g}$ ). The efficiency of the removal was evaluated from the Qe (uptake of metal per unit weight of sorbent) obtained by the equation $1:{ }^{16}$

$$
Q e=\frac{(C i-C f) \times V}{m}
$$

where $\mathrm{Ci}\left(\mathrm{mg} \mathrm{L}^{-1}\right)$ is the $\mathrm{Ag}^{\mathrm{I}}$ initial concentration, $\mathrm{Cf}\left(\mathrm{mg} \mathrm{L}^{-1}\right)$ is the $\mathrm{Ag}^{\mathrm{I}}$ final or equilibrium concentration, $\mathrm{V}(\mathrm{L})$ is the volume of the test solution and $\mathrm{m}(\mathrm{g})$ is the sorbent mass.

\section{Isotherm adsorption}

The experiments were carried out at a temperature range of between 25 and $28^{\circ} \mathrm{C}$, using $50.0 \mathrm{mg}$ of non-shelled M. oleifera seeds $(500 \mu \mathrm{m})$ and $50 \mathrm{~mL}$ of $\mathrm{Ag}^{\mathrm{I}}$ solution in a concentration of 5 to $100 \mathrm{mg} \mathrm{L}^{-1}$. The $\mathrm{pH}$ of the mixture was adjusted at 6.5 using $0.5 \mathrm{~mol} \mathrm{~L}^{-1} \mathrm{NaOH}$ and extraction time was $20 \mathrm{~min}$. The mixture was filtrated and the $\mathrm{Ag}^{\mathrm{I}}$ was quantified using flame atomic absorption spectrometry.

\section{Ag $g^{I}$ determination}

Standard solutions of $\mathrm{Ag}^{\mathrm{I}}$ were prepared from $1000 \mathrm{mg} \mathrm{L}^{-1} \mathrm{Ag}^{\mathrm{I}}$ (Carlo Erba, Val de Reuil, France). The $\mathrm{Ag}^{\mathrm{I}}$ was quantified using an atomic absorption spectrometer (SpectrAA-220 Varian, Victoria, Australia). Instrumental conditions such as wavelength of $328.3 \mathrm{~nm}$, slit of $0.1 \mathrm{~nm}$, current lamp of $4.0 \mathrm{~mA}$, air flow rate of 13.5 $\mathrm{L} \mathrm{min}^{-1}$ and acetylene flow rate of $2.0 \mathrm{~L} \mathrm{~min}^{-1}$ were used.

\section{Studies of interferent ions on the removal of $A g^{I}$}

The removal of $\mathrm{Ag}^{\mathrm{I}}$ in the presence of $\mathrm{Pb}^{\mathrm{II}}, \mathrm{Cu}^{\mathrm{II}}, \mathrm{Cd}^{\mathrm{II}}$ and $\mathrm{Co}^{\mathrm{II}}$, in various proportions, denominated by concomitant ions, was evaluated using non-shelled M. oleifera seeds. The experimental conditions were: particle size of $500 \mu \mathrm{m}$, extraction time of $20 \mathrm{~min}$, sorbent mass of $2.0 \mathrm{~g}$ and $\mathrm{pH}$ of 6.5 .

\section{Application of the proposed method}

The proposed sorbent was applied to residue obtained from chemistry classes, residue tested for chemical oxygen demand in this institution; film developing solution and residue from graphic material, obtained from local businesses. These effluents contained $\mathrm{Ag}^{\mathrm{I}}, \mathrm{Pb}^{\mathrm{II}}, \mathrm{Cu}^{\mathrm{II}}, \mathrm{Cd}^{\mathrm{II}}$ and $\mathrm{Co}^{\mathrm{II}}$ ions. Samples were filtered through filter paper and the $\mathrm{pH}$ adjusted at 6.5 , using $0.5 \mathrm{~mol} \mathrm{~L}^{-1} \mathrm{NaOH}$. One hundred milliliters samples were shaken with $2.0 \mathrm{~g}$ of non-shelled 
M. oleifera seeds for $20 \mathrm{~min} \mathrm{Ag}^{\mathrm{I}}$ was quantified using FAAS before and after removal experiments.

\section{Results and Discussion}

\section{Biosorbent characterization}

The main functional groups present in the M. oleifera seeds were characterized by infrared material analysis. The broadband centered at $3420 \mathrm{~cm}^{-1}$ can be attributed to $\mathrm{O}-\mathrm{H}$ stretching of the connection in this protein, fatty acids, carbohydrates and the lignin units. Due to the seed high protein content there is also a relevant contribution to this region because of $\mathrm{N}-\mathrm{H}$ stretching in the bondage of amides. ${ }^{18}$ The peaks that appear in 2923 and $2852 \mathrm{~cm}^{-1}$ correspond respectively to the asymmetric and symmetric stretching of the connection of the $\mathrm{C}-\mathrm{H}$ in $\mathrm{CH}_{2}$ group. Due to the high intensity of these bands it is possible to assign them to the predominantly lipid component of the seed that is present in high proportion similar to the proportion of the protein. ${ }^{19}$ In the 1800 to $1500 \mathrm{~cm}^{-1}$ region there are a number of overlapping bands between 1750 and $1630 \mathrm{~cm}^{-1}$. This set can be attributed to the $\mathrm{C}=\mathrm{O}$ connection stretching. Owing to the heterogeneous type of seed, the carbonyl group may be linked to different neighborhoods as part of the fatty acid portion of lipid and protein portion of the amides. The carbonyl that appears due to the lipid component in 1740 and $1715 \mathrm{~cm}^{-1}$, which can be observed in the spectrum as a small peak or shoulder part of the main band at $1658 \mathrm{~cm}^{-1}$, was assigned to the carbonyl amides in the protein portion. The peak at $1587 \mathrm{~cm}^{-1}$ can be attributed to the stretching of the $\mathrm{C}-\mathrm{N}$ linkage and the deformation of the $\mathrm{N}-\mathrm{H}$ linking proteins present in the seed jug. Literature reports that M. oleifera Lam. seeds present a protein mass composition of $29.36 \%$. ${ }^{20}$ Figure 1 presents the seeds infrared spectrum.

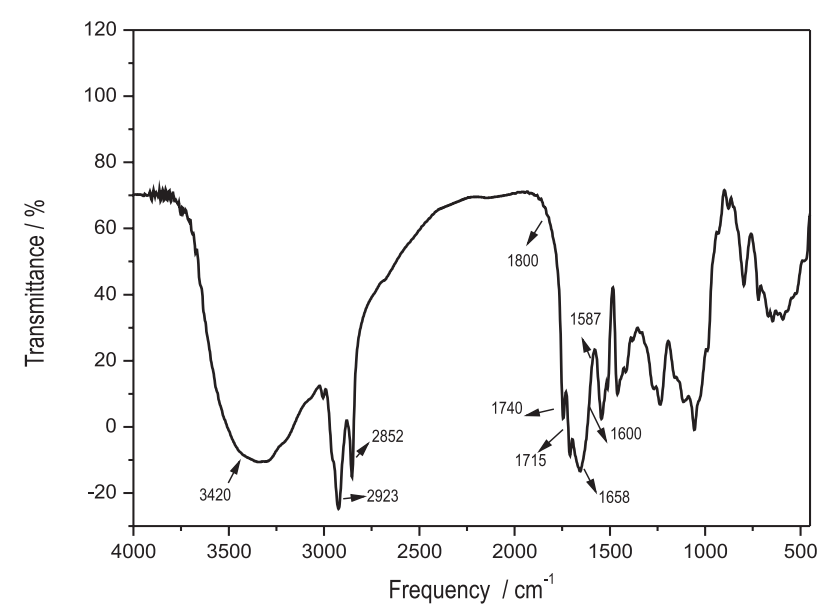

Figure 1. FT-IR spectrum of Moringa oleifera seeds.

\section{Studies of sorption variables}

Figure 2 shows Qe values in the function of sorbent mass for non-shelled and shelled seeds and husk using $5.0 \mathrm{mg} \mathrm{L}^{-1} \mathrm{Ag}^{\mathrm{I}}$. It was observed that husks showed more efficiency for $\mathrm{Ag}^{\mathrm{I}}$ removal than non-shelled and shelled seeds for quantities of $50 \mathrm{mg}$ of sorbent or less. However, in quantities of sorbent above $50 \mathrm{mg}$, differences were not observed between non-shelled and shelled seeds and husk. Significant differences were not observed for the test-F with a $95 \%$ assurance. Therefore, non-shelled seeds were used for further studies.

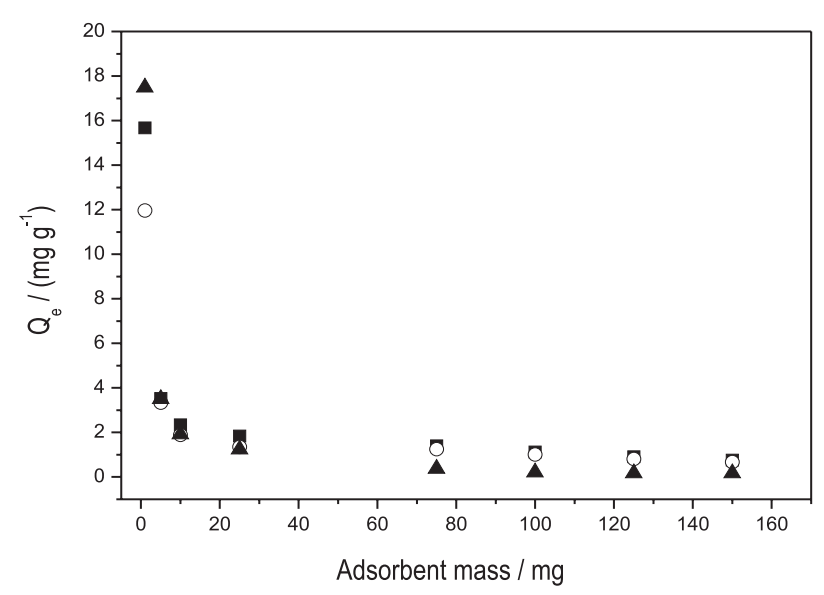

Figure 2. Capacity of sorption of the Moringa oleifera seeds in the $\mathrm{Ag}^{\mathrm{I}}$ removal. Experimental conditions: Extraction time $=5 \mathrm{~min}$; $\mathrm{pH}=6.5$; Volume of $\mathrm{Ag}^{\mathrm{I}}=25.0 \mathrm{~mL}$; Concentration of $\mathrm{Ag}^{\mathrm{I}}=5.0 \mathrm{mg} \mathrm{L}^{-1}$. non-shelled seeds, $\boldsymbol{\Delta}$ husk, $\bigcirc$ shelled seeds.

The following variables were studied: particle size of sorbent, $\mathrm{pH}$, time of extraction, sorbent mass, metal concentration and volume of $\mathrm{Ag}^{\mathrm{I}}$ solution.

Qe values in function of the adsorbent particle size (500, 180 and $75 \mu \mathrm{m}$ ) were obtained (Figure 3). A decrease in particle size showed a favorable effect on metal sorption justified by an increase in the adsorbent surface area. However, particle sizes of 180 and $75 \mu \mathrm{m}$ were not used because the filtration step was very slow. Moreover, Qe values were similar, i.e., 0.289 and $0.301 \mathrm{mg} \mathrm{g}^{-1}$ for $\leq 500 \mu \mathrm{m}$ and $\leq 75 \mu \mathrm{m}$, respectively.

The effect of $\mathrm{pH}$ range on $\mathrm{Ag}^{\mathrm{I}}$ adsorption was studied from 2.0 to 8.0 (Figure 4). The conditions were: $500 \mu \mathrm{m}$ particle size, 20 min extraction time, $4.0 \mathrm{~g}$ adsorbent mass and $50 \mathrm{~mL}$ of $25.0 \mathrm{mg} \mathrm{L}^{-1} \mathrm{Ag}^{\mathrm{I}}$. Optimum values of Qe were obtained in $\mathrm{pH}>4.0$; above this Qe values were found constant.

Biosorbent materials primarily contain weak acidic and basic functional groups. This is in accordance to the acidbase equilibria theory, in the $2.5-5 \mathrm{pH}$ range, the binding of heavy metal cations is primarily determined by the 


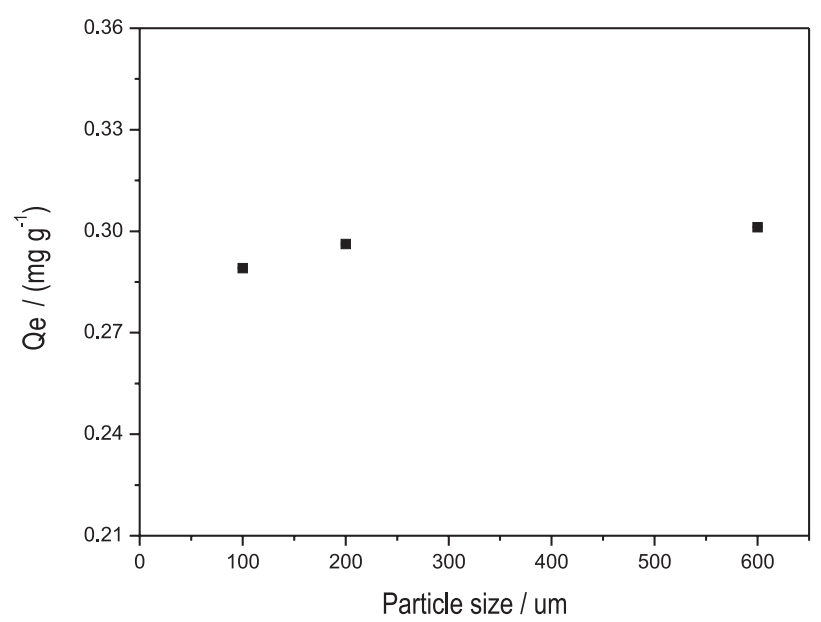

Figure 3. $\mathrm{Ag}^{\mathrm{I}}$ removal in the function of the particle size. Experimental conditions: Extraction time $=20 \mathrm{~min}$; Moringa oleifera mass $=4.0 \mathrm{~g}$.; Volume of $\mathrm{Ag}^{\mathrm{I}}=50.0 \mathrm{~mL} ; \mathrm{pH}=6.5$; Concentration of $\mathrm{Ag}^{\mathrm{I}}=$ $25.0 \mathrm{mgL}^{-1}$.

state of dissociation of the weak acidic groups. Carboxyl groups $(-\mathrm{COOH})$ are the important groups for metal uptake by biological materials. ${ }^{16}$ The ionic states of cell wall functional groups can be used to explain the $\mathrm{pH}$ dependence of biosorption. Low $\mathrm{pH}$ conditions allow hydrogen and hydronium ions to compete with metal binding sites on the biomass, causing a poor uptake. At higher $\mathrm{pH}$ values, 5-7, there is a lower number of competing hydrogen ions and more ligands are exposed with negative charges, resulting in greater sorption. Whereas at a $\mathrm{pH}>7$, it occurs the solution precipitation, leading to a reduction sorption capacity. ${ }^{16}$ These results are in accordance with literature. Therefore, the $6.5 \mathrm{pH}$ value was then chosen for further studies.

The effect of extraction time on $\mathrm{Ag}^{\mathrm{I}}$ sorption was studied in the 5 to 50 min range. Figure 5 shows that the amount of silver ions retained by the adsorbent material

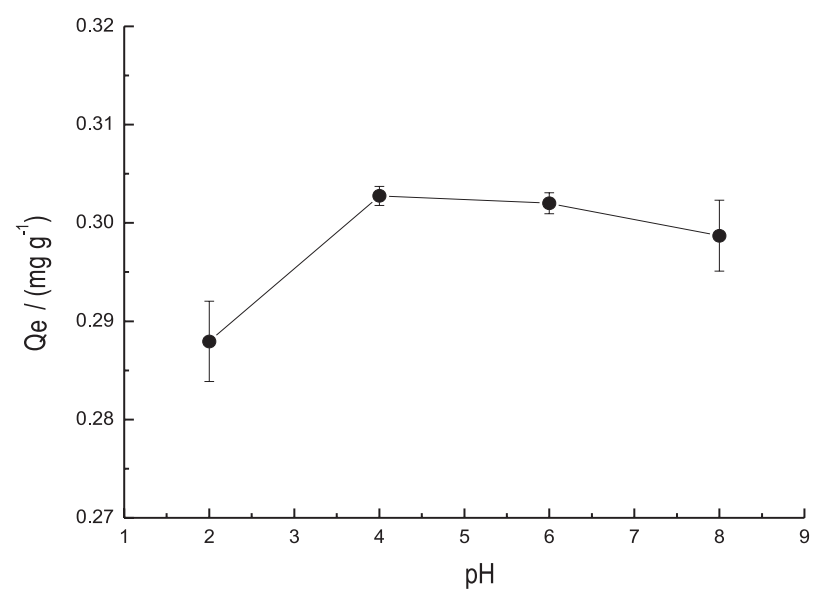

Figure 4. $\mathrm{Ag}^{\mathrm{I}}$ removal in the function of the $\mathrm{pH}$. Experimental conditions: particle size $=500 \mu \mathrm{m}$; Extraction time $=20 \mathrm{~min}$; Moringa oleifera mass $=4.0 \mathrm{~g}$.; Volume of $\mathrm{Ag}^{\mathrm{I}}=50.0 \mathrm{~mL}$; Concentration of $\mathrm{Ag}^{\mathrm{I}}=25.0 \mathrm{mg} \mathrm{L}^{-1}$. increased considerably for up to $20 \mathrm{~min}$ and was constant after that. The time of $20 \mathrm{~min}$ was chosen due to the good results presented in the removal $\left(\mathrm{Qe}=0.302 \mathrm{mg} \mathrm{g}^{-1}\right)$ and the shortest time for sorption process.

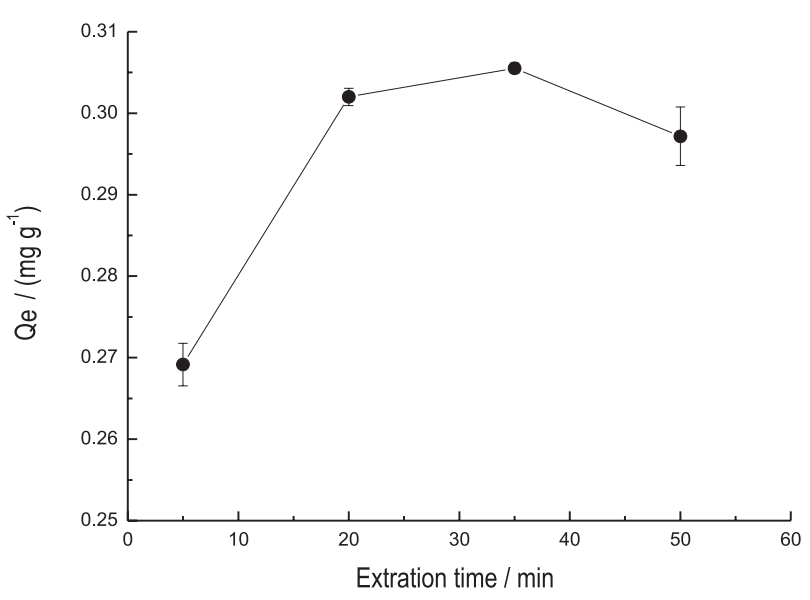

Figure 5. Capacity of sorption of the Moringa oleifera in the function of extraction time. Experimental conditions: particle size $=500 \mu \mathrm{m} ;$ Moringa oleifera mass $=4.0 \mathrm{~g}$.; Volume of $\mathrm{Ag}^{\mathrm{I}}=50.0 \mathrm{~mL} ; \mathrm{pH}=6.5$; Concentration of $\mathrm{Ag}^{\mathrm{I}}=25.0 \mathrm{mg} \mathrm{L}^{-1}$.

Figure 6 shows the removal studies made using $25 \mathrm{mg} \mathrm{L}^{-1} \mathrm{Ag}^{\mathrm{I}}$ and non-shelled $M$. oleifera seeds from 0.1 to $4.0 \mathrm{~g}$. The results show that the uptake of quantity of adsorbed metal per unit weight of sorbent decreases suddenly until $1.0 \mathrm{~g}$ of $M$. oleifera, indicating an increase in the $\mathrm{Ag}^{\mathrm{I}}$ removal. In the 1.0 to $4.0 \mathrm{~g}$ interval, the Qe values remained constant probably due to the equilibrium reached.

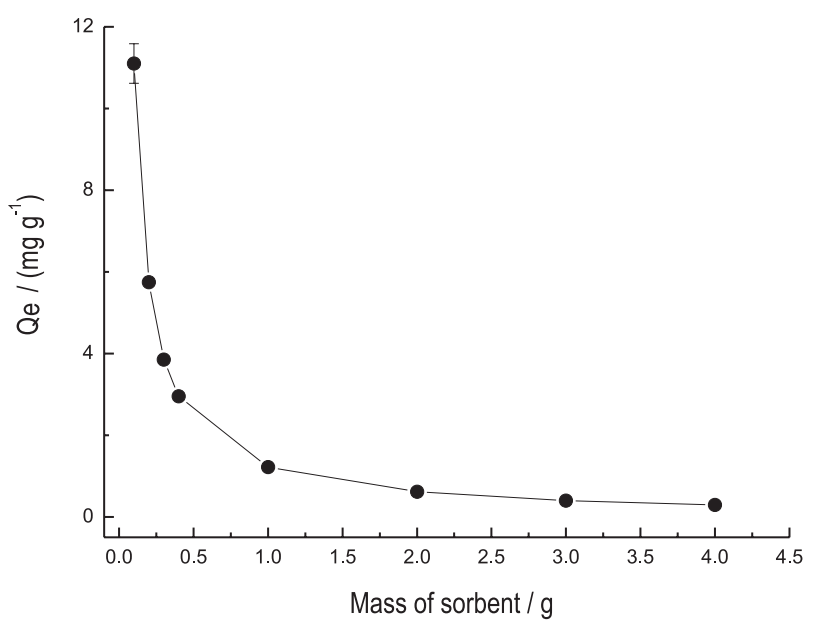

Figure 6. Effect of Moringa oleifera mass on sorption of $\mathrm{Ag}^{\mathrm{I}}$. Experimental conditions: particle size $=500 \mu \mathrm{m} ; \mathrm{pH}=6.5 ;$ Extraction time $=$ $20 \mathrm{~min}$; Concentration of $\mathrm{Ag}^{\mathrm{I}}=25.0 \mathrm{mg} \mathrm{L}^{-1}$; Volume of $\mathrm{Ag}^{\mathrm{I}}=50.0 \mathrm{~mL}$.

\section{Isotherm adsorption}

One of the important physicochemical aspects for the sorption process evaluation is the equilibrium of sorption. 
Figure 7 shows the isotherm sorption of $\mathrm{Ag}^{\mathrm{I}}$ on non-shelled M. oleifera seeds.

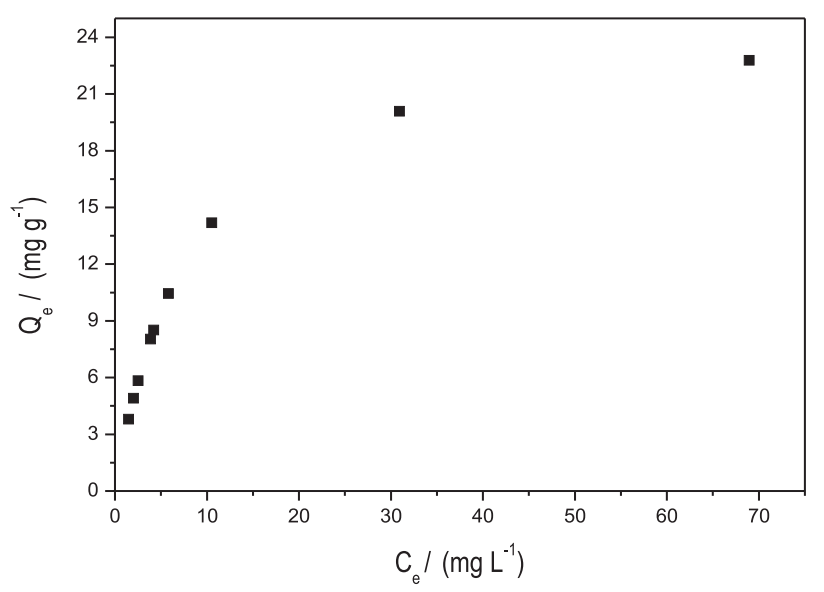

Figure 7. Adsorption isotherm for $\mathrm{Ag}^{\mathrm{I}}$ by Moringa oleifera seeds. Experimental conditions: size of particle $=500 \mu \mathrm{m} ; \mathrm{pH}=6.5$; Concentration of $\mathrm{Ag}^{\mathrm{I}}=5.0$ at $100 \mathrm{mg} \mathrm{L}^{-1}$; Extraction time $=20 \mathrm{~min}$; Moringa oleifera mass $=50 \mathrm{mg}$. (A).

The isotherm curve obtained indicates favorable adsorption process and highlights the strong tendency of the process for monolayer formation. Therefore, the extent of sorption was adequate to the Langmuir model. The Langmuir equation assumes that adsorption is limited to the monolayer and a maximum adsorption indicates saturation of this monolayer. The experimental results obtained were plotted (correlation coefficient of 0.99352) in Langmuir isotherm linear equation from 5 to $100 \mathrm{mg} \mathrm{L}^{-1} \mathrm{Ag}^{\mathrm{I}}$ (Figure 7). The plot of Ce/Qe versus Ce gives a straight line of slope 1/Qmax and intercept 1/Qmaxb. The magnitude with Langmuir Qmax and b constants show adsorption capacity of $23.13 \mathrm{mg}$ of $\mathrm{Ag}^{\mathrm{I}}$ per gram of non- shelled $M$. oleifera seeds and adsorption energy of $0.1586 \mathrm{~L} \mathrm{mg}^{-1}$, respectively.

\section{Comparison of the present study with other adsorbents}

The present study showed that Moringa oleifera seeds demonstrated good removal capacities for $\mathrm{Ag}^{\mathrm{I}}$ $\left(23.13 \mathrm{mg} \mathrm{g}^{-1}\right)$ as compared to the reports with other adsorbents (Table 1).

\section{Studies of interferent ions in the removing of $A g^{I}$}

Removing of $\mathrm{Ag}^{\mathrm{I}}$ in the presence of $\mathrm{Pb}^{\mathrm{II}}, \mathrm{Cu}^{\mathrm{II}}, \mathrm{Cd}^{\mathrm{II}}$ and $\mathrm{Co}^{\mathrm{II}}$ ions was studied in the following conditions: $500 \mu \mathrm{m}$ particle size, $20 \mathrm{~min}$ extraction time, $2.0 \mathrm{~g}$ adsorbent mass, $6.5 \mathrm{pH}$ and $100 \mathrm{~mL} \mathrm{Ag}^{\mathrm{I}}$ volume. The results are shown in Table 2. The influence of interferents was verified by comparing the percentages of removal of a solution containing only $\mathrm{Ag}^{\mathrm{I}}$ and a solution containing $\mathrm{Ag}^{\mathrm{I}}$ ions and interferent ion. Removal percentage was calculated based on analytical signals obtained before and after the removal procedure and the tests performed in triplicate.

In this study, a specie is considered as interferent for the removal of $\mathrm{Ag}^{\mathrm{I}}$ in the proposed procedure, when the difference between the values of removal of the solution containing only ions $\mathrm{Ag}^{\mathrm{I}}$ and those containing the possible interfering ions is more than $10 \%{ }^{25}$

Thus, the interference factor, IF, is defined by equation 2:

$\mathrm{IF}=\mathrm{A}^{\prime} / \mathrm{A}$

where $\mathrm{A}^{\prime}$ is the value of the percentage of removal on the solution of $\mathrm{Ag}^{\mathrm{I}}$ in the presence of possible interference, and $\mathrm{A}$ is the percentage of removal on the solution of $\mathrm{Ag}^{\mathrm{I}}$ in the absence of possible interference.

In this case, $\mathrm{IF}=1.00$ means that there is no interference, while factors greater than 1.10 or smaller than 0.90 indicate an increase or a decrease of analytical signal due to interference.

Table 3 shows the results of removal of $\mathrm{Ag}^{\mathrm{I}}$ in real samples. The values obtained satisfactory confirm the excellent potential for removal of ions $\mathrm{Ag}^{\mathrm{I}}$ using M. oleifera Lam seeds. The methodology is simple, low cost and can therefore be used in remediation techniques.

Table 1. Comparison with other adsorbents

\begin{tabular}{lcc}
\hline Absorbent & $\begin{array}{c}\text { Maximum adsorption } \\
\text { capacity (mg g })^{-1}\end{array}$ & Reference \\
\hline Resin Amberlite XAD-16 & 4.66 & 21 \\
Modified silica gel using 2,4,6-trimorpholino-1,3,5-triazin & 0.384 & 22 \\
Naphitalene modified with dithizone & 0.029 & 23 \\
Octadecil silica membrane disks modified by (CBT) & 0.214 & 24 \\
M. oleifera seeds & 23.13 & This work \\
\hline
\end{tabular}

CBT-1,3-bis (2- cyanobenzene) triazine. 
Table 2. Effect of interferent ions on the removal of $\mathrm{Ag}^{\mathrm{I}}$. Experimental conditions: Particle size $=500 \mu \mathrm{m}$, extraction time $=20 \mathrm{~min}$, mass of adsorbent $=2.0 \mathrm{~g}, \mathrm{pH} 6.5$

\begin{tabular}{ccc}
\hline $\begin{array}{c}\text { Proportion analyte: } \\
\text { interferent }\end{array}$ & $\begin{array}{c}\text { Removal \% of } \\
\mathrm{Ag}^{\mathrm{I}}\end{array}$ & $\begin{array}{c}\text { Interference } \\
\text { Factor (IF) }\end{array}$ \\
\hline $1: 0$ & 99.32 & 1.00 \\
$1: 0.2$ & 99.65 & 1.00 \\
$1: 0.1$ & 98.61 & 0.99 \\
$1: 1$ & 99.96 & 1.01 \\
$1: 5$ & 99.97 & 1.01 \\
$1: 10$ & 99.98 & 1.01 \\
\hline
\end{tabular}

Table 3. Results of the removal of $\mathrm{Ag}^{\mathrm{I}}$ ions in the samples

\begin{tabular}{lccc}
\hline Samples & $\begin{array}{c}\text { Initial conc. } \\
\left(\mathrm{mg} \mathrm{L}^{-1}\right)\end{array}$ & $\begin{array}{c}\text { Final conc. } \\
\left(\mathrm{mg} \mathrm{L}^{-1}\right)\end{array}$ & Removal \% \\
\hline Residue of chemistry classes & 339.0 & 27.1 & 92 \\
$\begin{array}{l}\text { Residue of chemical oxygen } \\
\text { demand testing }\end{array}$ & 4267.0 & 768.1 & 82 \\
$\begin{array}{lcc}\text { Solution of photographic film } \\
\text { Residue of graphic material }\end{array}$ & 5284.5 & 475.6 & 91 \\
\hline
\end{tabular}

${ }^{*} \mathrm{ND}=$ no detected.

\section{Conclusions}

In this work non-shelled $M$. oleifera seeds were used as sorbent for removing $\mathrm{Ag}^{\mathrm{I}}$ in aqueous solutions. The optimum conditions for removing $\mathrm{Ag}^{\mathrm{I}}$ were: $2.0 \mathrm{~g}$ of adsorbent with 75-500 $\mu \mathrm{m}$ particle size, 20 min extraction time and $6.5 \mathrm{pH}$. The adsorption capacity was $23.13 \mathrm{mg}$ of $\mathrm{Ag}^{\mathrm{I}}$ per gram of $M$. oleifera seeds. The proposed method has advantages, such as, the low cost of sorbent, high efficiency and the minimization of chemical sludge. The sorbent is an alternative material for chemical remediation and is economical and environmental friendly.

\section{Acknowledgments}

The authors are grateful for the financial support from the Conselho Nacional de Desenvolvimento Cientifíco e Tecnológico (CNPq), Fundação de Amparo a Pesquisa do Estado de Minas Gerais (FAPEMIG) and the Coordenação de Aperfeiçoamento de Pessoal de Nível Superior (CAPES).

\section{References}

1. Brauner, C. J.; Wood, C. M.; Comp. Biochem. Physiol., Part C: Toxicol. Pharmacol. 2002, 133, 161.
2. Rahman, M. A.; Kaneco S.; Amin Md. N.; Suzuki T.; Ohta K. Talanta 2004, 62, 1047.

3. Kurniawan, T. A., Chan, G. Y.S., Wai-Hung Lo., Babel, S.;Chem. Eng. J. 2006, 118, 83.

4. Malkoc, E., Nuhoglu, Y.;J. Hazard. Mater. 2005, 127, 120.

5. Zulkali, M. M. D.; Ahmad, A. L.; Norulakmal, N. H.; Bioresour. Technol. 2006, 97, 21.

6. Cabuk, A., Akar, T., Tunali, S., Gedikli, S.; Chem. Eng. J. 2007, 131, 293.

7. Demirbas, A.; J. Hazard. Mater. 2008, 157, 220.

8. Azila, Y.Y., Mashitah, M. D., Bhatia S.; Bioresour. Tecnol. 2008, 99, 8549 .

9. Qi, B.C., Aldrich, C.; Bioresour. Tecnol. 2008, 99, 5595.

10. Park, D., Lim S. R., Yun Y. S., Park, J. M.; Bioresour. Tecnol. 2008, 99, 8810.

11. Fan, T.; Liu, Y.; Feng, B.; Zeng, G.; Yang, C.; Zhou, M. Zhou, H.; Tan, Z.; Wang, X.; J. Hazard. Mater. 2008, 160, 655.

12. Razmovski, R.; Ciban, M. S.; Ecol. Eng. 2008, 34, 179.

13. Gupta, V. K.; Rastogi, A.; Coll. Surf. B: Biointerfaces 2008, 64, 170.

14. Tarley, C. R. T.; Ferreira, S. L. C.; Arruda, M. A. Z.; Microchem. J. 2004, 77, 163.

15. Sharma, P.; Kumari, P.; Srivastava, M. M.; Srivastava, S.; Bioresour. Technol. 2007, 98, 474.

16. Bhatti, H. N.; Mumtaz, B.; Hanif,M. A.; Nadeem, R.; Process Biochem. 2007, 42, 547.

17. Gassenschmidt, U.; Jany, K. D.; Tauscher, B.; Niebergall, H.; Biochim. Biophys. Acta 1995, 1243, 477.

18. Stuart, B.; Infrared Spectroscopy: Fundamentals and Applications, $1^{\text {st }}$ ed., John Wiley \& Sons, Inc.: England, 2004.

19. Brito, E. S.; Gallão, M. I.; Damasceno, L. F.; Revista Ciência Agronômica 2006, 37, 106.

20. Farooq, A.; Rashid, U.; Pak. J. Bot. 2007, 39, 1443.

21. Tunçeli, A.; Turker, A. R.; Talanta 2000, 51, 889.

22. Madrakian T.; Afkhami, A.; Zolfigol M. A.; Solgi M.; J. Hazard. Mater. 2006, 128, 67.

23. Fathi, M. R.; Pourreza, N.; Purweis, S.; J. Chin. Chem. Soc. 2009, 56, 825 .

24. Rofouei, M. K.; Payehghadr, M.; Shamsipur M.; Ahmadalinezhad A.; J. Hazard. Mater. 2009, 68, 1184.

25. Coelho, N. M. M.; PhD Thesis, Universidade Estadual de Campinas, Brazil, 1995. http://biq.iqm.unicamp.br/arquivos/ teses/vtls000103859.pdf. 